\title{
BUILDING AN INCLUSIVE COMMUNITY FOR AGAMA AND KEPERCAYAAN GROUPS: A Case Study of Indonesia Merayakan Perbedaan (IMP) of East Java
}

\author{
Asep Sandi Ruswanda \\ Universitas Gadjah Mada, Yogyakarta, Indonesia \\ E-mail: ruswandasandi@mail.ugm.ac.id \\ Samsul Maarif \\ Universitas Gadjah Mada, Yogyakarta, Indonesia \\ E-mail: samsul.maarif75@ugm.ac.id
}

\begin{abstract}
This study focuses on Indonesia Merayakan Perbedaan (IMP)'s works to build social inclusion for agama (religion) and kepercayaan (faith) groups. The Constitutional Court's decision No. 97/PUU-XIV/2016 was for sure a political turning point expected to eliminate stigma, discrimination, and recognition gaps between agama and kepercayaan groups. However, those were still prevalent. More alternative and creative work is still in need. This study demonstrates that IMP can be a model for building an inclusive community for agama and kepercayaan groups. IMP found ways to effectively instrumentalize the decision for diversity celebration. It managed diversity for inclusion in four phases: 1) raising awareness, creating understanding and encouraging reflection, 2) developing a vision of inclusion, 3) rethinking key management concepts and principles, and 4) adapting systems and processes. In doing so, IMP maximized opportunities and minimized challenges for the sustainability of its work in building an inclusive community. IMP's participation in building social inclusion was a form of community intervention at a community level on ecological pathways to social inclusion. This study argues that community intervention such as IMP is significantly considerable to promote individual, organizational, community, and socio-political transformations to social inclusion, especially for inclusive interreligious relationships for agama and kepercayaan groups.
\end{abstract}

Keywords: Agama; diversity management; inclusive community; kepercayaan; social inclusion.

Article history: Received: 16 June 2021; Revised: 21 July 2021; Accapted: 16 August 2021; Available online: 01 September 2021 


\section{How to cite this article:}

Ruswanda, Asep Sandi, and Samsul Maarif. "Building an Inclusive Community for Agama and Kepercayaan Groups: A Case Study of Indonesia Merayakan Perbedaan (IMP) of East Java". Religio: Jurnal Studi Agama-agama 11, no. 2 (2021): 117-138. https://doi.org/10.15642/religio.v11i2.1766

\section{Introduction}

The issuance of the Constitutional Court's decision No. 97/PUU-XIV/2016 provides legal recognition to followers of kepercayaan that are equal to agama followers. This decision is a political turning point expected to eliminate stigma, discrimination, and recognition gaps between agama and kepercayaan groups. A number of organizational figures from agama groups responded to this decision, such as Yunahar Ilyas and Din Syamsudin ${ }^{1}$ from Muhammadiyah, Masduki Baidlowi, ${ }^{2}$ Robikin Emhas ${ }^{3}$ from Nahdlatul Ulama, and Gomar Gultom ${ }^{4}$ from Communion of Churches in Indonesia (PGI). However, agama groups do not always respond positively as expected. For example, the official protests coming from MUI through its eight statements show that the stigma that agama and kepercayaan are not equal entities still occurs. ${ }^{5}$

Since Indonesia's independence, kepercayaan groups have become victims of the politics of agama stigmatizing kepercayaan groups as primitive, animist ${ }^{6}$ pseudo-religion, budaya (culture),

1 A Aziz, "Muhammadiyah Khawatir Penghayat Kepercayaan Masuk Kolom Agama KTP," last modified November 8, 2017, https://tirto.id/muhammadiyah-khawatirpenghayat-kepercayaan-masuk-kolom-agama-ktp-czQt.

2 A. P. Taher, "PBNU Sebut Putusan MK Tidak Koordinasi Dengan Kementerian Agama.," last modified November 9, 2017, https://tirto.id/pbnu-sebutputusan-mktidak-koordinasi-dengan-kementerian-agama-czRN.

3 Mabruroh, "NU Hormati Putusan MK Untuk Penghayat Kepercayaan," last modified November 9, 2017, https://www.republika.co.id/berita/nasional /politik/17/11/09/oz5071-nuhormati-putusan-mk-untuk-penghayat-kepercayaan.

4 Markus, "Sekum PGI: Keputusan MK Terkait UU Adminduk Sebuah Langkah Maju," last modified November 10, 2017, https://pgi.or.id/sekum-pgi-keputusanmkterkait-uu-adminduk-sebuah-langkah-maju.

5 F. Wulandari, "8 Pernyataan Sikap MUI Tanggapi Putusan MK Terkait 'Pencantuman Kolom Aliran Kepercayaan Di e-KTP,"' last modified January 17, 2018, https://www.tribunnews.com/nasional/2018/01/17/8-pernyataan-sikapmuitanggapi-putusan-mk-terkait-pencantuman-kolom-aliran-kepercayaandi-e-ktp.

6 Michel Picard, 'Introduction: 'Agama,' 'Adat,' and Pancasila," in The Politics of Religion in Indonesia: Syncretism, Orthodoxy, and Religious Contention in Java and Bali, ed. Michel Picard and Rémy Madinier, 2011, 1-20. 
communists, ${ }^{7}$ uncivilized, ${ }^{8}$ "orang yang belum beragama" (people who do not yet have a religion), and backward" as MUI accused. At the regulatory and policy level, the state regulates in a discriminatory manner kepercayaan groups, at least through TAP MPR No. IV/MPR/1978, Law No. 1/PNPS/1965, Law No. 16 of 2004 Article 30 paragraph (3), Regulation of the Republic of Indonesia Prosecutor's Office No. 5 of 2019, and Circular of the Minister of Home Affairs No.477/4054. ${ }^{10}$ Although there is nothing in the constitution and laws that explicitly define agama or "recognized" religion, in practice, kepercayaan is conceptualized as an entity of "non-agama" ("unrecognized" religion), referring to the explanation of Law no. 1/PNPS/1965 concerning blasphemy-which states Islam, Protestantism, Catholicism, Hinduism, Buddhism, and Confucianism are historical facts of religions embraced by Indonesians without defining it. ${ }^{11}$

A number of scholars emphasize the study of agama and kepercayaan as a socio-political subject. Geertz typologies Javanese society into abangan (the Javanese syncretism), santri (the purer Islam), and priyayi (the hereditary aristocracy), ${ }^{12}$ while Ricklefs divided into putiban (the "white ones") and abangan (the "red (or brown) ones"). Putiban is pious and devout Javanese Muslims, while abangan is Javanese who was not prepared to accept these new and more demanding versions of Islam. ${ }^{13}$ Picard problematizes the separation of

\footnotetext{
7 S. Maarif, Pasang Surut Rekognisi Agama Lelubur Dalam Politik Agama Di Indonesia (Center for Religious and Cross-cultural Studies (CRCS), 2017).

8 Abdul Mu'ti and Ahmad Najib Burhani, "The Limits of Religious Freedom in Indonesia: With Reference to the First Pillar Ketuhanan Yang Maha Esa of Pancasila," Indonesian Journal of Islam and Muslim Societies 9, no. 1 (May 24, 2019): 111134.

${ }^{9}$ Kate O'Shaughnessy, Gender, State and Social Power in Contemporary Indonesia: Divorce and Marriage Law (London: Routledge, 2009); Martin Ramstedt, Hinduism in Modern Indonesia: A Minority Religion between Local, National, and Global Interests (London: RoutledgeCurzon, 2004).

${ }^{10}$ Engkus Ruswana, "Strategi Advokasi Dan Pengembangan Jaringan," August 24, 2020; Sukirno Sukirno, "Diskriminasi Pemenuhan Hak Sipil Bagi Penganut Agama Lokal," Administrative Law and Governance Journal 1, no. 3 (December 5, 2018): 231239.

11 Zainal Abidin Bagir, “'Kepercayaan' Dan 'Agama' Dalam Negara PascaReformasi," Prisma 39, no. 1 (2020): 41-52.

${ }^{12}$ C. Geertz, The Religion of Java (The University of Chicago Press, 1960).

13 M. C. Ricklefs, Islamisation and Its Opponents in Java: A Political, Social, Cultural and Religious History, c. 1930 to Present (NUS Press, 2019), accessed March 29, 2021,
} 
the terms "agama" and "adat." He saw that traditional Indonesian society did not separate them. ${ }^{14}$ In addition, a study of the relationship between agama and kepercayaan groups or social inclusion for kepercayaan groups after the Constitutional Court's decision No. 97/PUU-XIV/2016 limited. A number of studies only focus on social inclusion programs under the program of the Coordinating Ministry of Development and Culture (Kemenko PMK), that is, Program Peduli (Care Program) such as Maarif et al. (2019), ${ }^{15}$ Baskoro (2020), ${ }^{16}$ Mubarok (2020), ${ }^{17}$ and Adzkiya \& Fadhilah (2020). ${ }^{18}$

This study focuses on building social inclusion towards agama and kepercayaan groups. Social inclusion has two major dimensions, namely the interpersonal dimension and the public dimension. The interpersonal dimension can occur in a private setting, such as in someone's home, while the public dimension involves community participation to encourage all groups to have equal access. An organization or group has a potential role in building social inclusion. ${ }^{19}$ This study proposes a model for building social inclusion through community intervention initiated by agama and kepercayaan. This study refers to an inclusive interreligious group in Sidoarjo, East Java, which is called Indonesia Merayakan Perbedaan (Indonesia Celebrating Diversity, IMP). This group consists of agama and kepercayaan groups. They co-build social inclusion for agama and

https:/ / resolver.ebscohost.com/Redirect/PRL?EPPackageLocationID=1118986.1 644094.45286714\&epcustomerid=s2947694.

14 Picard, "Introduction: 'Agama,' 'Adat,' and Pancasila."

15 Samsul Maarif et al., Merangkul Penghayat Kepercayaan Melalui Advokasi Inklusi Sosial: Belajar Dari Pengalaman Pendampingan (Program Studi Agama dan Lintas Budaya (Center for Religious and Cross-cultural Studies, CRCS) Sekolah Pascasarjana Lintas Disiplin, Universitas Gadjah Mada, 2019).

16 Aji Baskoro, "Mewujudkan Social Inclusion: Kontribusi Satunama terhadap Penghayat Kepercayaan di Yogyakarta," Panangkaran: Jurnal Penelitian Agama dan Masyarakat 3, no. 2 (August 15, 2020): 181-196.

17 Husni Mubarok, "Advokasi Inklusi Sosial Dan Politik Kewarganegaraan: Pengalaman Advokasi Penghayat Marapu Di Pulau Sumba, Nusa Tenggara Timur," Tashwirul Afkar 39, no. 01 (November 23, 2020): 1-31.

18 Ubbadul Adzkiya and Iman Fadhilah, "Inklusi Sosial Penghayat Kepercayaan; Upaya Mendorong Hak Warga Negara Penganut Kepercayaan Sedulur Sikep Kudus," At-Taqaddum 12, no. 1 (August 3, 2020): 91.

19 Stacy Clifford Simplican et al., "Defining Social Inclusion of People with Intellectual and Developmental Disabilities: An Ecological Model of Social Networks and Community Participation," Research in Developmental Disabilities 38 (March 2015): 18-29. 
groups. IMP's participation in building social inclusion was a form of community intervention at a community level on ecological pathways to social inclusion. This study argues that community interventions such as IMP can encourage individual, organizational, community, and socio-political change towards social inclusion.

\section{An Overview of IMP}

IMP is an interreligious group of religious figures representing six agama groups and one figure representing kepercayaan groups. IMP is located in Sidoarjo, East Java. The name IMP arises from the idea that various ethnicities, religions, races, and so on in Indonesian have to be grateful and enjoyed together. IMP views that diversity is a great asset to realize shared goals, as Indonesia's motto, Bbinneka Tunggal Ika (Unity in Diversity). ${ }^{20}$

IMP was founded and driven by seven interreligious figures from both agama and kepercayaan groups. They are the founders and kind of the "brand ambassadors" of IMP. They are Mohammad Nizam As-Shofa (Islamic religious figure), Simon Filantropha (Protestant religious figure), Yohanes Agus Sulistyo (Catholic religious figure), I Nyoman Sutantra (Hindu religious figure), Tedjapuñño Mahāthera (Buddhist religious figure), K.R.T. Bingky Irawan Hadinegoro (Confucian religious figure), and Naen Soeryono (Kepercayaan religious figure).

The initial idea of establishing IMP began when Mohammad Nizam As-Shofa met M. Mas'ud Adnan and Djadi Galajapo from BBS TV in early 2018 at Pondok Pesantren (Islamic boarding school) of Ahlus-Shofa Wal Wafa. They discussed their idea to hold an interreligious dialogue program with religious figures in East Java. On February 12, 2018, a meeting was held involving religious figures from agama and kepercayaan groups at Mahamada Café. About 25 people from agama and kepercayaan groups attended the meeting. They all agreed to make an interreligious dialogue program on BBS TV. They were finally able to hold a shoot for the first interreligious program on March 12, 2018. IMP then as a group or institution officially established on May 23, 2018 (Notary Deed No. 10) and legalized by the Ministry of Law and Human Rights with Number AHU-0007168.AH.01.07 in 2018.

20 Indonesia Merayakan Perbedaan, "Company Profile Indonesia Merayakan Perbedaan” (Indonesia Merayakan Perbedaan, 2020). 


\section{IMP's Responses on Legal Recognition of Kepercayaan}

The Constitutional Court's decision No. 97/PUU-XIV/2016 stated that Article 61 paragraph (1) and Article 64 paragraph (1) of Civic Administration Law are contrary to the 1945 Constitution of the Republic of Indonesia (UUD NRI 1945) and do not have legally binding force conditionally as long as they do not include kepercayaan; and, Article 61 paragraph (2) and Article 64 paragraph (5) of Civic Administration Law are contrary to the 1945 Constitution of the Republic of Indonesia and do not have binding legal force. ${ }^{21}$ In essence, the Constitutional Court only decided on two legal substances. First, Article 61 paragraph (1) and Article 64 paragraph (1) of Civic Administration Law are determined conditionally unconstitutional. Conditionally unconstitutional means that if the article petitioned for being tested is unconstitutional when the decision is read out, the article will become constitutional if the Constitutional Court's requirements can be met. Second, Article 61 paragraph (2) and Article 64 paragraph (5) of Civic Administration Law were unconstitutional. It means that the judges of the Constitutional Court decided that the word agama in Article 61 paragraph (1) and Article 64 paragraph (1) of Civic Administration Law must be interpreted as such, including kepercayaan in filling out the religion column in the electronic identity card (KTP-el) and family card $(\mathrm{KK}) .^{22}$

IMP's responses to the Constitutional Court's decision No. 97/PUU-XIV/2016 are civic engagement: working to respond to civic issues and participate in the life of society and build capacities of knowledge, skills, values and motivation to improve the conditions of citizens and the future of society. ${ }^{23}$ Civic engagements may be divided into two types, which are indirect and direct civic engagement.

First, the emergence of IMP is an indirect civic engagement. IMP took the momentum of the Constitutional Court's decision No. 97/PUU-XIV/2016. The emergence of IMP in early 2018 is historically adjacent to the Constitutional Court's decision (end of

\footnotetext{
21 “Salinan Putusan Nomor 97/PUU-XIV/2016" (Mahkamah Konstitusi RI, 2017), https://peraturan.bpk.go.id/Home/DownloadUjiMateri/23/97_PUU-

XIV_2016.pdf.

22 P. J. Hairi, “Tindak Lanjut Putusan MK Terkait Penganut Kepercayaan," Info Singkat, 2017.

${ }^{23}$ R. P. Adler and J. Goggin, "What Do We Mean by 'Civic Engagement'?," Journal of transformative education 3, no. 3 (2005): 236-253.
} 
2017). This can be interpreted as a civic engagement to engage themselves and the public in the civic issue of recognition of those excluded citizens, mainly groups of kepercayaan, as stated in the Constitutional Court's decision.

Second, IMP's responses are direct civic engagements. IMP religious figures respond positively to recognition of kepercayaan. Generally speaking, they support, respect, and accept the Constitutional Court's decision No. 97/PUU-XIV/2016. IMP's main figures believe that the decision is the best decision for religious diversity in Indonesia, particularly for followers of kepercayaan.

Table 1.1

IMP's Responses to the Constitutional Court's decision No.

97/PUU-XIV/2016

\begin{tabular}{|l|l|l|}
\hline Figure & $\begin{array}{l}\text { Religious } \\
\text { Beliefs }\end{array}$ & $\begin{array}{l}\text { Response to the } \\
\text { Constitutional Court's } \\
\text { decision No. 97/PUU- } \\
\text { XIV/2016 }\end{array}$ \\
\hline $\begin{array}{l}\text { Mohammad Nizam } \\
\text { As-Shofa }\end{array}$ & Islam & $\begin{array}{l}\text { Fully support and respect the } \\
\text { decision }\end{array}$ \\
\hline Simon Filantropha & Protestantism & Totally agree with the decision \\
\hline $\begin{array}{l}\text { Yohanes Agus } \\
\text { Sulistyo }\end{array}$ & Catholicism & Accept the decision \\
\hline I Nyoman Sutantra & Hinduism & Agree with the decision \\
\hline $\begin{array}{l}\text { Tedjapuñño } \\
\text { Mahāthera }\end{array}$ & Buddhism & $\begin{array}{l}\text { The decision is the best and } \\
\text { must be obeyed }\end{array}$ \\
\hline $\begin{array}{l}\text { K.R.T. Bingky } \\
\text { Irawan Hadinegoro }\end{array}$ & Confucianism & Complying with the decision \\
\hline Naen Soeryono & Kepercayaan & $\begin{array}{l}\text { The decision made followers } \\
\text { of kepercayaan more confident }\end{array}$ \\
\hline
\end{tabular}

\section{Managing Diversity in IMP}

According to Kirton and Greene, the term managing diversity was popularized by Kandola \& Fullerton (1998), ${ }^{24}$, which aims to show managing diversity as a new way forward for equality in

${ }^{24}$ R. S. Kandola and Johanna Fullerton, Diversity in Action: Managing the Mosaic, 2nd ed., Developing strategies (London: Institute of Personnel and Development, 1998). 
policymaking. ${ }^{25}$ The basic concept of diversity management realizes that people's population is diverse. ${ }^{26}$ Cox defines managing diversity as "creating a climate in which the potential advantages of diversity for organizational or group performance are maximized while the potential disadvantages are minimalized." ${ }^{27}$ Managing diversity in IMP aims to create inclusive spaces for all groups. ${ }^{28} \mathrm{I}$ borrow Pless and Maak's (2004) work on building a culture of inclusion to explain how IMP manages diversity in four phases: 1) raising awareness, creating understanding and encouraging reflection, 2) developing a vision of inclusion, 3) rethinking key management concepts and principles, and 4) adapting systems and processes.

First, it is raising awareness, creating understanding and encouraging reflection. Raising awareness is realizing that there are people who are different in their religious beliefs. To recognize other different realities, raising awareness can be started from a series of discursive learning processes aiming to increase awareness. Discursive processes are to realize and integrate viewpoints, voices, backgrounds, and other differences rooted in social, ethnicity, culture, gender, religion, and so on. Besides, it is essential to avoid privileging certain groups and marginalize other groups. This is the critical point of integrating and creating social inclusion. ${ }^{29}$ In each of its activities, IMP provided the same and equal portion to each group. In doing so, IMP avoided privileging or marginalizing certain groups. IMP developed an awareness that all groups have equal rights. IMP renounced the dichotomy of majority and minority groups or dominant and subordinate groups. Then, it is creating a shared understanding. For such a purpose, it is important to identify a common moral foundation and reflect on different fundamental assumptions on which certain thoughts and behaviors are based. It is basically about creating and reproducing shared discourses as relational processes

\footnotetext{
25 Gill Kirton and Anne Marie Greene, The Dynamics of Managing Diversity: A Critical Approach, Fourth edition. (London: New York: Routledge, Taylor \& Francis Group, 2016).

${ }^{26}$ Kandola and Fullerton, Diversity in Action.

27 T. Cox, Cultural Diversity in Organizations: Theory, Research, and Practice (BerrettKoehler Publishers, 1993).

28 Indonesia Merayakan Perbedaan, "Company Profile Indonesia Merayakan Perbedaan."

29 Nicola M. Pless and Thomas Maak, "Building an Inclusive Diversity Culture: Principles, Processes and Practice,” Journal of Business Ethics 54 (2004): 129-147.
} 
which would lead to social inclusion. The basic assumptions about social inclusion work out through processes of group integration into a common goal. ${ }^{30}$ IMP's moral foundation is that diversity must be celebrated. It was inspired by the national slogan, Bhinneka Tunggal Ika, which wanted to make diversity a uniting force. The fundamental assumption is that the diversity in Indonesian is a shared strength and all groups are brothers/sisters. It also reflects in IMP's own slogan, namely "semua saudara" (all are brothers/sisters), which means that every human being should regard anyone as his own brother/sister who has to love without favoritism. Shared discourses as relational processes are the topics of interreligious dialogue that IMP holds. In general, IMP discusses social life, national issues, and religious spiritual matters. The relational process aims to strengthen the common goal of IMP, which is that all people or groups are brothers/sisters as its slogans. In addition, diversity management is inseparable from works for encouraging reflection. Critical reasoning and dialogue for encouraging reflection are needed to strengthen awareness and mutual understanding. Reflection was also encouraged by IMP through many interreligious dialogues and interreligious activities such as weekly jagongan (literally means casual chit-chat), diversity festival, and religious holidays celebration.

The second is developing a culture of inclusion. Developing a culture of inclusion requires a clearly inclusive vision. The vision provides a platform for change, provides a common mental framework, describes the future, and clarifies the position that a group wants to achieve. ${ }^{31}$ IMP realizes that a vision of inclusion navigates the goals that IMP seeks to achieve. The vision of inclusion of IMP emphasizes tolerance, cooperation, organizing and participating in interreligious activities actively, and building positive and inclusive communication. The vision of IMP is to become a group that actively promotes and socializes tolerance and cooperation among religious communities throughout Indonesia, especially in East Java. The missions of IMP are to organize and participate in interreligious activities actively, and to build positive and inclusive communication for all segments of society across ethnicities, religions,

\footnotetext{
${ }^{30}$ Ibid.

31 Francis J. Gouillart and James N. Kelly, Transforming the Organization (New York: McGraw-Hill, 1995); J. P. Kotter, Leading Change (Harvard business press, 1996).
} 
races, and groups. ${ }^{32}$ Regarding the relationship between agama and kepercayaan groups, IMP's vision of inclusion clearly places followers of kepercayaan in an equal position to followers of agama. Developing a vision of inclusion in managing diversity needs to involve certain aspects in it, which is mutual recognition, building and maintaining a culture of communication that upholds the norms of inclusion and mutual trust, providing equal rights and opportunities for every individual and group, and appreciating contributions and showing sensitivity to other groups.

Third, one of the essential instruments in managing diversity is rethinking the key management concepts and principles that form the organization's basis. ${ }^{33}$ The concepts and principles of inclusion critically need to be rethought and renewed. In dealing with that, IMP digs for reflection and rethinking about inclusion concepts from experts. IMP invites experts to reflect and rethink how to manage diversity and build social inclusion. IMP provides a forum in weekly jagongan for them. Those involved in it include scholars, activists in NGOs, religious figures outside IMP, youth leaders, women leaders, government officials, and other figures involved and concerned about the discourse on diversity and social inclusion in Indonesia. It is done to get ideas, input, and knowledge from experts. By reflecting on the concepts and principles in IMP, it can be conceptualized in three concepts and principles following Pless and Maak's work (2004). Those are the principles of inclusion, inclusive leadership, and dialogue and participation.

The last is adapting systems and processes. Adapting systems and processes aims for two things, namely, creating competencies of inclusion and development of inclusion. Pless and Maak believe that individuals or communities require certain qualities and traits called competencies of inclusion. ${ }^{34}$ Building competencies of inclusion can derive from founding principles of inclusion, namely the principle of mutual recognition, reciprocal understanding, standpoint plurality \& mutual enabling, trust, integrity, and intercultural moral point of view. ${ }^{35}$ Competencies of inclusion also can translate in more detail

32 Indonesia Merayakan Perbedaan, "Company Profile Indonesia Merayakan Perbedaan."

33 Pless and Maak, "Building an Inclusive Diversity Culture: Principles, Processes and Practice."

${ }^{34}$ Ibid.

35 Ibid. 
into observable behaviors. For instance, those are showing respect and empathy, acknowledging differences and equality, encouraging open and inclusive communication to all groups, involving participation, and encouraging cooperation between all groups. ${ }^{36} \mathrm{I}$ believe that IMP's vision of inclusion fits into the inclusion competency, as Pless and Maak explain. For example, inclusive communication and collaboration across religious groups also include IMP's vision of inclusion. Another goal of adapting systems and processes is the development of inclusion. The development of inclusion in IMP is done through a number of development programs such as weekly jagongan, diversity festivals, and community engagement in commemoration of religious holidays. Those programs are considered the development of inclusion measures. The development of inclusion programs also aims to increase the competencies of inclusion of people involved in IMP itself.

\section{Opportunities and Challenges}

As observed, IMP has challenges and opportunities consisting of internal and external factors. Internal opportunities refer to internal factors that can provide advantages to sustain what IMP has worked and established for inclusive interreligious relationships between agama and kepercayaan groups. Internal opportunities are common principles or perspectives on faith, shared goals, and trust and interconnection among religious groups.

First, the same principle of faith is opportunity in the management of interreligious relations. ${ }^{37}$ All religious leaders in IMP believe that the teachings of their faith are in line with the principles of social inclusion. Among arguments about social inclusion promoted by IMP coming from the basic theological understanding of its religious figures. The theological arguments used by religious leaders to support social inclusion in IMP, for example, are Islamic Sufism, Nostra Aetate from Catholicism, the Noble Eightfold Path from Buddhism, and Tat Twam Asi from Hinduism.

Second, IMP has an internal opportunity which is shared goals. Shared goals will navigate the vision of inclusion and drive the social

\footnotetext{
${ }^{36}$ Ibid.

${ }^{37}$ Charles K Moywaywa, "Management of Religious Conflicts in Kenya: Challenges and Opportunities," International Journal of Education and Research 6, no. 1 (2018): 129_ 142.
} 
action of all individuals involved in a group. Shared goals are able to provide a good opportunity for various religious groups involved in a group to get closer and work together to achieve social inclusion. ${ }^{38}$ The idea of shared goals can come from a knowledge base. ${ }^{39} \mathrm{By}$ reflecting on Indonesia's national knowledge base, namely Bbinneka Tunggal Ika (unity in diversity), IMP builds a narrative that all humans are brothers/sisters. IMP articulates and translates the slogan Bhinneka Tunggal Ika for shaping shared goals. IMP brings ideas about diversity, tolerance, cooperation, brotherhood/sisterhood, openness and equality as shared goals.

Third, IMP's internal opportunity is trust and interconnection among religious groups. Interconnection among religious groups strengthens interreligious relations among religious groups within IMP. The interconnection between religious groups is related to each other's trust. "Building trust requires clarifying misunderstandings, removing negative perceptions and stereotypes, and transforming enemy images. ${ }^{40}$ In IMP, religious leaders clarify misunderstandings, negative perceptions and stereotypes, enemy images, and stigmas on kepercayaan groups. Also, IMP emphasizes equality and equity to build trust and interconnection. World religions such as "apples and oranges" cannot be compared. However, "apples and oranges" are all related in their nature as fruits. They can relate to each other and understand each other as fellow fruit. It does not explain which fruit is perfect, but to say that there is a need for trust. ${ }^{41}$ According to Putnam, "the more we connect with other people, the more we trust them, and vice versa." ${ }^{2}$ It shows that the more interreligious communities connect with other religious communities, the more they trust each other. To do this, IMP does a variety of ways. For example, IMP involves all different religious groups in its activities or celebrations of a particular religious group, such as maulidan or

\footnotetext{
38 Ibid.

39 Paul Hedges, Inter-Religious Relations: Conceptualising Social Cohesion in Relation to Religious Diversity: Sketching a Pathway in a Globalised World (S. Rajaratnam School of International Studies, 2020).

40 S. Ayse Kadayifci-Orellana, "Inter-Religious Dialogue and Peacebuilding," in The Wiley-Blackwell Companion to Inter-Religious Dialogue, ed. Catherine Cornille (Wiley, 2013), 149-167.

${ }^{41}$ Catherine Cornille, The Im-Possibility of Interreligious Dialogue (New York: Crossroad, 2008).

42 Robert D. Putnam, "Tuning In, Tuning Out: The Strange Disappearance of Social Capital in America," Political Science and Politics 28, no. 4 (1995): 664-683.
} 
slametan. When the Islamic groups in IMP celebrate maulidan, other religious groups also get involved. When kepercayaan groups practice slametan, other religious groups are also involved. Trust and interconnection among religious groups in IMP also help spread shared goals.

Internal challenges are limitations within IMP and what makes IMP complicated. I consider that the internal challenges of IMP are figure-centered, community self-reliance, time and financial challenges, and gender disparity.

First, IMP emphasizes the roles of religious figures as its center. On the one hand, religious figures' involvement in interreligious activities to build social inclusion is good because religious figures have high authority, legitimacy, and credibility to convey messages powerfully to the congregation. On the other hand, figure-centered has a lot of drawbacks. Interreligious activities carried out in the long term require high commitment from religious figures, including time. Meanwhile, religious leaders have a shortage of time. ${ }^{43}$ So, IMP can distribute its main tasks, functions, powers to members so that the sustainability of IMP agendas does not depend on the religious figure (-centered) alone.

Second, it is community self-reliance. Self-reliance is one of the foundations for effective community development. ${ }^{44}$ "Self-reliance is not merely a necessity but a matter of survival." 45 There are some obstacles to self-reliance in IMP. First, IMP as a legally registered institution has not been able to build good organizational governance. IMP has not distributed its duties, functions, and authorities proportionally. The sustainability of IMP is still very much dependent on the role of the main figures. Second, IMP has not been able to fully cultivate the resources of all group members. "Self-reliance in community development demands that community members apply their knowledge and skills to the resources at their disposal." 46 IMP has not yet maximized the potential, knowledge, and skills of its

\footnotetext{
${ }^{43}$ Kadayifci-Orellana, "Inter-Religious Dialogue and Peacebuilding."

44 C.C. Fonchingong and L.N. Fonjong, "The Concept of Self-Reliance in Community Development Initiatives in the Cameroon Grassfields," GeoJournal 57, no. $1 / 2$ (2002): 83-94.

${ }^{45}$ Johan Galtung, Peter O’ Brien, and Roy Preiswerk, eds., Self-Reliance: A Strategy for Development (London: Bogle-L'Ouverture Publications, 1980).

46 Fonchingong and Fonjong, "The Concept of Self-Reliance in Community Development Initiatives in the Cameroon Grassfields."
} 
group members who come from various religious backgrounds. Third, IMP has not been able to properly manage its network with government institutions or NGOs. IMP has started to do that with the local government of East Java, NGOs, and scholars, but this has not yet been maximized. Probably because IMP is a group that was only founded about three years ago, the network has not been fully connected.

Third, the following internal challenges for IMP are time and finances. Building inclusive interreligious relations is a long and costly process. ${ }^{47}$ Religious leaders sometimes had limited time to be continuously involved in IMP's activities. Many of the religious leaders are also religious leaders in their religion. The challenge will come when one religious group does not have representation in IMP's activities because the main figure in that religious group did not name his replacement figure. In addition, financial support in the long term is an internal challenge for IMP. For example, IMP faces financial challenges when BBS TV provides a limited budget when the weekly jagongan program is held by BBS TV. It ultimately made IMP more focused on online platforms because of lower costs and broader reach. Losing financial support can end the process of sustaining inclusive interreligious relationships before achieving goals. $^{48}$

Fourth, IMP's internal challenge is gender disparity. The absence of female figures in the gender composition of IMP's main figures is a significant issue for IMP to be concerned about. It is assumingly due to the influence of a tradition of religious leadership that is mainly male-dominated. The involvement of women in interreligious actions is no less important. Engaging women's perspectives and voices in interreligious activities can broaden the conception of religious leadership and women's participation to build inclusive interreligious relationships. ${ }^{49}$ IMP has actually attempted to accommodate gender formation in weekly jagongan. Even though the main figures of IMP are all men, IMP provides opportunities for women to become speakers in the weekly jagongan. When celebrating Kartini's Day or Mother's Day, IMP specifically shows female panels in weekly jagongan. Nevertheless, apart from "women's days," in terms

\footnotetext{
${ }^{47}$ Kadayifci-Orellana, "Inter-Religious Dialogue and Peacebuilding."

48 Ibid.

${ }^{49}$ Ibid.
} 
of quantity, there is still quite a significant disparity between male and female speakers in IMP weekly jagongan.

External opportunities are external factors by which advantages for the sustainability of IMP. IMP's external opportunities include networking, the role of new media and the internet, and the Indonesian constitution and laws.

First, it is networking. One of the trends that are happening in the world is the increasing participation of grassroots movements and organizations to build inclusive interreligious relationships. ${ }^{50}$ In Indonesia, there are many governmental institutions, such as the Ministry of Education and Culture, Ministry of Home Affairs, and Local Government, or non-governmental organizations such as Satunama, YLBHI, and Gusdurian, that are involved in engaging issues of agama and kepercayaan relationship. Also, IMP can use Interreligious group networks, such as ICRP, DIAN Interfidei, and Jakatarub, or religious organizations, such as PBNU, MLKI, PGI, KWI, PHDI, PERMABUDHI, and MATAKIN to build networks mutually.

Second, one of the tools that can facilitate the sustainability of inclusive interreligious relations is through new media and the internet. New media and the internet made it possible to quickly disseminate information, organize community organizations more efficiently, and connect community networks. The use of new media and the internet can increase social engagement and participation in inclusive interreligious sustainability. ${ }^{51}$ IMP utilizes social media sites on Facebook, Instagram and YouTube as new media to actively mobilize the masses and socialize their interreligious activities. During the Covid-19 pandemic era, digital possibilities are taking on a more significant role. IMP creatively modifies the weekly jagongan into weekly online jagongan through the Zoom meeting application, and then it is distributed to their YouTube channel.

Third, the constitution and laws can benefit the sustainability of inclusive interreligious relationships for agama and kepercayaan groups. The Indonesian constitution guarantees the existence of agama and kepercayaan. First, articles related to human rights in

\footnotetext{
${ }^{50}$ Julia Sheetz-Willard et al., "Interreligious Dialogue Reconsidered: Learning from and Responding to Critique and Change," Joumal of Ecumenical Studies 47, no. 2 (2012).

51 Ibid.
} 
general, namely Article 27, Article 28, Article 28A, Article 28B, Article 28C, Article 28D, Article 28F, Article 28G, Article 28H, and Article 28J. Second, articles are specifically related to agama and kepercayaan, namely Article $28 \mathrm{I}$ and Article 29. Third, the article related to the guarantee of freedom to maintain and develop cultural values, namely Article 32. In addition, several laws also cover the rights of followers of kepercayaan, namely: Law no. 1 of 1974 concerning Marriage, the Constitutional Court's decision No. 97/PUU-XIV/2016 concerning Civic Administration, Law no. 16 of 2017 concerning Mass Organizations, Law no. 5 of 2017 concerning the Advancement of Culture, and Law no. 3 of 1999 concerning Human Rights. ${ }^{52}$

External challenges are factors outside of IMP that challenge the sustainability of building social inclusion and the vision of inclusion developed by IMP. The external challenges IMP is facing are hardliners and the infiltration of political actors into the community.

First, the sustainability of interreligious relations or the management of religious conflicts is often constrained by the hardline attitudes taken by certain individuals or groups. Some people or groups may not even realize they are part of a hardline group. Hardliners can be seen in how they plan and run their organizations. ${ }^{53}$ Hardliners increased after the 1998 reformation in Indonesia. Factors that caused the increase of hardliners are: 1) they have access to facilities and institutions for religious and political mobilization, including the state apparatus, and 2) the rise of conservative Muslim politicians. ${ }^{54}$ IMP itself sometimes received negative comments because such as being considered to associate with "kafir"forbidden by hardliners.

Second, the infiltration of political actors into an interreligious community can divide the community itself. Political contestation is often related to certain identities such as religion and ethnicity, which often demands loyalty to a specific identity. Political differences that infiltrate the community can challenge inclusive processes of

\footnotetext{
52 Ruswana, "Strategi Advokasi Dan Pengembangan Jaringan."

53 Moywaywa, "Management of Religious Conflicts in Kenya: Challenges and Opportunities."

54 Kikue Hamayotsu, "The Limits of Civil Society in Democratic Indonesia: Media Freedom and Religious Intolerance," Journal of Contemporary Asia 43, no. 4 (November 2013): 658-677.
} 
managing diversity. ${ }^{55}$ General elections held in Indonesia opened up opportunities for political actors to infiltrate interreligious groups such as IMP. Political actors often invite IMP main figures to be involved in general elections, whether at the central or local levels. They want to use IMP's main figures as vote-getters because they have a large congregation and significantly influence society. IMP itself does not want to get involved in practical politics. If IMP is engaged in practical politics, what is the difference between IMP and political parties which compartmentalize individuals? IMP doesn't want to do that the way political parties do. ${ }^{56}$ The main figures kept IMP free from the infiltration of political elements. ${ }^{57}$

\section{Ecological Pathways to Social Inclusion}

Social inclusion is "the process of improving the terms of participation in society, particularly for people who are disadvantaged, through enhancing opportunities, access to resources, voice and respect for rights." ${ }^{58}$ Social inclusion is also defined as "the process of improving the ability, opportunity, and dignity of people, disadvantaged on the basis of their identity, to take part in society." There is no clear mechanism for increasing social inclusion and reducing social exclusion. It is because many factors influence social exclusion. ${ }^{60}$

Here, I propose a model of community participation to build ecological pathways to social inclusion from Simplican et al. (2015). This approach argues that the roles of individual, interpersonal, organizational, community, and socio-political are opportunities as well as challenges for sustaining social inclusion. Individual is enabling or disabling conditions for a person, which includes the level of functioning, self-motivation, confidence, knowledge, and the use of

55 Moywaywa, "Management of Religious Conflicts in Kenya: Challenges and Opportunities."

56 I Nyoman Sutantra, January 3, 2021.

${ }^{57}$ Yohanes Agus Sulistyo, November 24, 2020.

${ }^{58}$ Nationen Vereinte, ed., Leaving No One behind: The Imperative of Inclusive Development, Report on the world social situation 2016 (New York, NY: United Nations, 2016).

59 World Bank, ed., Inclusion Matters: The Foundation for Shared Prosperity, New Frontiers of Social Policy (Washington, D.C: The World Bank, 2013).

60 The Asia Foundation, Understanding Social Exclusion in Indonesia: A Meta-Analysis of Program Peduli's Theory of Change Documents (The Asia Foundation, 2016). 
goal setting. Individuals can increase happiness, self-esteem, and a sense of belonging. Yet, it can also lead to a sense of loneliness. ${ }^{61}$

Interpersonal is enabling or disabling conditions which can include relationships with family members, friends, and so on. It is also related to the relationship between excluded group participation in the community, including the attitudes of community members therein. The interpersonal product of social inclusion can increase respect, trust, and social capital. Conversely, negative interpersonal relationships can result in discrimination in employment, services, and decreased social capital and self-esteem. ${ }^{62}$

Organizational is a condition that includes informal networks such as family and formal networks such as advocacy organizations, schools, houses of worship, employment centers, and law enforcement. Conditions at the family organization level include socioeconomic status, social capital, and culture. Every advocacy organization has a culture and management that may differ from one another in building and promoting social inclusion. ${ }^{63}$

Organizations at the community level also include schools, houses of worship, employment centers, and law enforcement. Organizational results from social inclusion include cultural changes in organizations that further emphasize inclusiveness. An inclusive organizational culture can improve individual and interpersonal conditions. ${ }^{64}$

Community is a condition at the community level which includes the type of living accommodation, such as size and setting, availability and access to public services, communities, and resources, and the availability of advocacy groups. Conditions at the community level also include attitudes, culture, and community discourses. ${ }^{65}$

Socio-political is a condition that includes laws and enforcement laws, market forces, state perspectives, and access to public services. Social inclusion, political change can influence each other. Increased social inclusion can have political effects and vice

61 Simplican et al., "Defining Social Inclusion of People with Intellectual and Developmental Disabilities."

62 Ibid.

${ }^{63}$ Ibid.

${ }^{64}$ Ibid.

65 Ibid. 
versa. Legislative cutbacks can be challenging and have a political effect on a political level. ${ }^{66}$

The pathways to social inclusion have challenges at every level, such as a lack of individual skills, unsupportive relationships with friends, non-inclusive organizational culture, societal attitudes that stigmatize certain groups, and political policies that do not support social inclusion.

\section{Conclusion}

Learning from IMP, IMP builds social inclusion as a form of community participation at the community level on ecological pathways to social inclusion. At a smaller level, organizational, diversity management of IMP can be conceptualized in four phases, that are 1) raising awareness, creating understanding and encouraging reflection, 2) developing a vision of inclusion, 3) rethinking key management concepts and principles, and 4) adapting systems and processes. By maximizing opportunities and minimizing challenges, community intervention such as IMP in this ecological model helps promote the transformations of individual, organizational, community, and socio-political to social inclusion. This study can encourage intellectuals, excluded groups, families, service providers, and policymakers to build social inclusion at every level for agama and kepercayaan groups.

\section{Acknowledgments}

We are indebted to Indonesia Merayakan Perbedaan (IMP) for conducting research on them. We also thank the Indonesia Endowment Fund for Education (LPDP) as the funder. This research is for the Center for Religious and Cross-cultural Studies (CRCS), Graduate School, Gadjah Mada University.

\section{References}

\section{Books and Journals}

Adler, R. P., and J. Goggin. "What Do We Mean by 'Civic Engagement'?" Journal of transformative education 3, no. 3 (2005): 236-253.

Adzkiya, Ubbadul, and Iman Fadhilah. "Inklusi Sosial Penghayat Kepercayaan; Upaya Mendorong Hak Warga Negara Penganut

66 Ibid. 
Kepercayaan Sedulur Sikep Kudus." At-Taqaddum 12, no. 1 (August 3, 2020): 91.

Aziz, A. "Muhammadiyah Khawatir Penghayat Kepercayaan Masuk Kolom Agama KTP.” Last modified November 8, 2017. https://tirto.id/muhammadiyah-khawatir-penghayat-

kepercayaan-masuk-kolom-agama-ktp-czQt.

Bagir, Zainal Abidin. “'Kepercayaan' Dan 'Agama' Dalam Negara Pasca-Reformasi.” Prisma 39, no. 1 (2020): 41-52.

Baskoro, Aji. "Mewujudkan Social Inclusion: Kontribusi Satunama terhadap Penghayat Kepercayaan di Yogyakarta." Panangkaran: Jurnal Penelitian Agama dan Masyarakat 3, no. 2 (August 15, 2020): 181-196.

Cornille, Catherine. The Im-Possibility of Interreligious Dialogue. New York: Crossroad, 2008.

Cox, T. Cultural Diversity in Organizations: Theory, Research, and Practice. Berrett-Koehler Publishers, 1993.

Fonchingong, C.C., and L.N. Fonjong. "The Concept of Self-Reliance in Community Development Initiatives in the Cameroon Grassfields." GeoJournal 57, no. 1/2 (2002): 83-94.

Galtung, Johan, Peter O' Brien, and Roy Preiswerk, eds. Self-Reliance: A Strategy for Development. London: Bogle-L'Ouverture Publications, 1980.

Geertz, C. The Religion of Java. The University of Chicago Press, 1960. Gouillart, Francis J., and James N. Kelly. Transforming the Organization. New York: McGraw-Hill, 1995.

Hairi, P. J. “Tindak Lanjut Putusan MK Terkait Penganut Kepercayaan.” Info Singkat, 2017.

Hamayotsu, Kikue. "The Limits of Civil Society in Democratic Indonesia: Media Freedom and Religious Intolerance." Journal of Contemporary Asia 43, no. 4 (November 2013): 658-677.

Hedges, Paul. Inter-Religious Relations: Conceptualising Social Cohesion in Relation to Religious Diversity: Sketching a Pathway in a Globalised World. S. Rajaratnam School of International Studies, 2020.

Indonesia Merayakan Perbedaan. "Company Profile Indonesia Merayakan Perbedaan.” Indonesia Merayakan Perbedaan, 2020.

Kadayifci-Orellana, S. Ayse. "Inter-Religious Dialogue and Peacebuilding." In The Wiley-Blackwell Companion to Inter-Religious Dialogue, edited by Catherine Cornille, 149-167. Wiley, 2013. 
Kandola, R. S., and Johanna Fullerton. Diversity in Action: Managing the Mosaic. 2nd ed. Developing strategies. London: Institute of Personnel and Development, 1998.

Kirton, Gill, and Anne Marie Greene. The Dynamics of Managing Diversity: A Critical Approach. Fourth edition. London: New York: Routledge, Taylor \& Francis Group, 2016.

Kotter, J. P. Leading Change. Harvard business press, 1996.

Maarif, S. Pasang Surut Rekognisi Agama Lelubur Dalam Politik Agama Di Indonesia. Center for Religious and Cross-cultural Studies (CRCS), 2017.

Maarif, Samsul, Husni Mubarok, Laela Fitriani Sahroni, and Dyah Roessusita. Merangkul Penghayat Kepercayaan Melalui Advokasi Inklusi Sosial: Belajar Dari Pengalaman Pendampingan. Program Studi Agama dan Lintas Budaya (Center for Religious and Cross-cultural Studies, CRCS) Sekolah Pascasarjana Lintas Disiplin, Universitas Gadjah Mada, 2019.

Mabruroh. "NU Hormati Putusan MK Untuk Penghayat Kepercayaan." Last modified November 9, 2017. https://www.republika.co.id/berita/nasional/politik/17/11/09 /oz5071-nuhormati-putusan-mk-untuk-penghayat-kepercayaan.

Markus. "Sekum PGI: Keputusan MK Terkait UU Adminduk Sebuah Langkah Maju.” Last modified November 10, 2017. https://pgi.or.id/sekum-pgi-keputusan-mkterkait-uuadminduk-sebuah-langkah-maju.

Moywaywa, Charles K. "Management of Religious Conflicts in Kenya: Challenges and Opportunities." International Journal of Education and Research 6, no. 1 (2018): 129-142.

Mubarok, Husni. "Advokasi Inklusi Sosial Dan Politik Kewarganegaraan: Pengalaman Advokasi Penghayat Marapu Di Pulau Sumba, Nusa Tenggara Timur." Tashwirul Afkar 39, no. 01 (November 23, 2020): 1-31.

Mu'ti, Abdul, and Ahmad Najib Burhani. "The Limits of Religious Freedom in Indonesia: With Reference to the First Pillar Ketuhanan Yang Maha Esa of Pancasila." Indonesian Journal of Islam and Muslim Societies 9, no. 1 (May 24, 2019): 111-134.

O'Shaughnessy, Kate. Gender, State and Social Power in Contemporary

Indonesia: Divorce and Marriage Law. London: Routledge, 2009.

Picard, Michel. 'Introduction: 'Agama,' 'Adat,' and Pancasila." In The Politics of Religion in Indonesia: Syncretism, Orthodoxy, and Religious 
Contention in Java and Bali, edited by Michel Picard and Rémy Madinier, 1-20, 2011.

Pless, Nicola M., and Thomas Maak. "Building an Inclusive Diversity Culture: Principles, Processes and Practice." Journal of Business Ethics 54 (2004): 129-147.

Putnam, Robert D. "Tuning In, Tuning Out: The Strange Disappearance of Social Capital in America." Political Science and Politics 28, no. 4 (1995): 664-683.

Ramstedt, Martin. Hinduism in Modern Indonesia: A Minority Religion between Local, National, and Global Interests. London: RoutledgeCurzon, 2004.

Ricklefs, M. C. Islamisation and Its Opponents in Java: A Political, Social, Cultural and Religious History, c. 1930 to Present. NUS Press, 2019. Accessed March 29, 2021. https://resolver.ebscohost.com/ Redirect/PRL?EPPackageLocationID=1118986.1644094.45286 714\&epcustomerid $=$ s2947694.

Ruswana, Engkus. "Strategi Advokasi Dan Pengembangan Jaringan"

Presented at the Workshop Penguatan Kapasitas Pengurus Organisasi Majelis Luhur Kepercayaan Terhadap Tuhan Yang Maha Esa Indonesia, August 24, 2020.

Sheetz-Willard, Julia, Per Faaland, Rebecca Mays, and Angela Ilic. "Interreligious Dialogue Reconsidered: Learning from and Responding to Critique and Change." Joumal of Ecumenical Studies 47, no. 2 (2012).

Simplican, Stacy Clifford, Geraldine Leader, John Kosciulek, and Michael Leahy. "Defining Social Inclusion of People with Intellectual and Developmental Disabilities: An Ecological Model of Social Networks and Community Participation." Research in Developmental Disabilities 38 (March 2015): 18-29.

Sukirno, Sukirno. "Diskriminasi Pemenuhan Hak Sipil Bagi Penganut Agama Lokal." Administrative Law and Governance Journal 1, no. 3 (December 5, 2018): 231-239.

Taher, A. P. "PBNU Sebut Putusan MK Tidak Koordinasi Dengan Kementerian Agama." Last modified November 9, 2017. https://tirto.id/pbnu-sebutputusan-mk-tidak-koordinasidengan-kementerian-agama-czRN.

The Asia Foundation. Understanding Social Exclusion in Indonesia: A Meta-Analysis of Program Peduli's Theory of Change Documents. The Asia Foundation, 2016. 
Vereinte, Nationen, ed. Leaving No One behind: The Imperative of Inclusive Development. Report on the world social situation 2016. New York, NY: United Nations, 2016.

World Bank, ed. Inclusion Matters: The Foundation for Shared Prosperity. New Frontiers of Social Policy. Washington, D.C: The World Bank, 2013.

Wulandari, F. "8 Pernyataan Sikap MUI Tanggapi Putusan MK Terkait 'Pencantuman Kolom Aliran Kepercayaan Di e-KTP."' Last modified January 17, 2018. https://www.tribunnews.com /nasional/2018/01/17/8-pernyataan-sikap-muitanggapiputusan-mk-terkait-pencantuman-kolom-aliran-kepercayaandie-ktp.

“Salinan Putusan Nomor 97/PUU-XIV/2016." Mahkamah

Konstitusi RI, 2017. https://peraturan.bpk.go.id/Home /DownloadUjiMateri/23/97_PUU-XIV_2016.pdf.

\section{Interview}

Sulistyo, Yohanes Agus, November 24, 2020.

Sutantra, I Nyoman, January 3, 2021. 